\title{
LARANGAN PRAKTEK \\ MONOPOLI DAN PERSAINGAN USAHA TIDAK SEHAT PENGECUALIAN-TERHADAP BADAN USAHA KOPERASI
}

\author{
Andjar Pachta Wirana ${ }^{1}$
}

\begin{abstract}
Abstrak
This article elaborates two law discourses regarding cooperative (koperasi) status and anti monopoly restriction. Under the Constitution of the Republic Indonesia the cooperative as people business unit is facilitated by economic policy. The policy has been aimed to delivery wider portion through economic system which closes to people. It has been known as people economic system with motto wider spread and national democratic economy. The author concedes to giving any exclusion to cooperative disregards toward anti monopoly law. Exclusion itself is explicitly reflected any legal protection from the State to people economic. It protection by shields and gives opportunity for cooperatives and small business units to develop and becomes strong in their business proportionally.
\end{abstract}

Kata kunci: hukum dagang, koperasi, pengecualian, undang-undang, anti monopoli

\section{Pendahuluan}

“...Kedudukan Badan-Usaha Koperasi di dalam sistim perekonomian Negara Indonesia memiliki dasar hukum yang kuat dan disebut secara eksplisit dalam konstitusi ${ }^{2}$; Pemerintah, sejak dari tahun pertama kemerdekaan Republik-Indonesia, dalam politik-ekonominya, selalu berusaha memberdayakan badan-usaha koperasi dengan membuat kebijakanekonomi yang memberikan porsi yang "luas" terhadap pengembangan dan perkembangan usaha koperasi secara nasional dalam rangka mewujudkan perekonomian yang berpihak kepada rakyat $^{3}$; yang kita kenal sekarang

\footnotetext{
${ }^{1}$ Penulis adalah Staf Pengajar Fakultas Hukum Universitas Indonesia.

${ }^{2}$ Undang-Undang Dasar 1945, Pasal 33 ayat (1).
} 
dengan sebutan "ekonomi kerakyatan"; dengan semboyan "pemerataan dan demokratisasi ekonomi nasional". Untuk inilah, maka dalam tata-ruang perekonomian nasional, -pada dasarnya- tidak ada tempat dan alasan yang memungkinan koperasi untuk melakukan monopoli dan praktek persaingan usaha yang tidak sehat. Pengecualian terhadap badan-usaha koperasi untuk tidak "tunduk" pada Ketentuan Perundang-Undangan yang mengatur tentang praktek monopoli dan persaingan tidak sehat tersebut, secara eksplisit menunjukankan bahwa adanya keberpihakan-juridis dari Pemerintah dan Negara kepada ekonomi-kerakyatan; dengan "melindungi" dan memberi kesempatan kepada badan-usaha koperasi dan usaha-kecil lain-nya untuk dapat berkembang dan menjadi kuat dalam bidang usahanya masing-masing secara proporsional ${ }^{4}$. Dengan demikian, ada "tiga hal-mendasar" yang terkandung dalam ketentuan tersebut; Pertama, Pengecualian tersebut diberikan kepada koperasi dalam melakukan kegiatan-usahanya untuk kepentingan para anggotanya; Kedua, Koperasi tunduk pada ketentuan UU No.5 Tahun 1999, bila memberikan pelayanan kepada masyarakat luas disamping memberikan pelayanan kepada anggota-nya; Ketiga, Koperasi yang memberikan pelayanan kepada masyarakat luas seperti disebut di atas tetap mendapat pengecualian, apabila sifat pelayanan yang diberikannya tidak mengakibatkan praktek monopoli dan persaingan tidak sehat. Selanjutnya, tetap dalam rangka usaha memperkokoh perekonomian rakyat, Pemerintah, juga disebutkan sebagai "Pembina" dari badan-badan-usaha koperasi yang ada di seluruh wilayah Indonesia ${ }^{5}$; Tugas pembinaan ini

${ }^{3}$ Untuk lebih jelas, Bung Hatta secara rinci menjelaskan latar belakang kedudukan dan fungsi Koperasi dalam rangka menghidupkan ekonomi rakyat agar secara nasional meningkatkan perekonomian bangsa dan Negara; lihat lebih lanjut: Masalah Politik Perekonomian Bagi Indonesia, Pidato Bung Hatta pada Pertemuan dengan Para Pemimpin Politik, Para Bankir, dan Para Ahli Pertanian di New York, Amerika Serikat, pada tanggal 06 Juni 1960. Selanjutnya lihat juga (baca), Keperluan Berkoperasi, Pidato Bung Hatta dalam Konperensi Kooperasi di Lausanne, pada tg1 09 Oktober 1961. Mohammad Hatta, Kumpulan Pidato II, Gunung Agung, Jakarta: 2002, hal. 138-182.

${ }^{4}$ Undang-Undang No.5 Tahun 1999, tentang larangan Praktek Monopoli dan persaingan usaha Tidak-Sehat; Pasal 50 huruf (i), Kegiatan Usaha koperasi yang secara khusus untuk melayani anggota-nya. Penjelasan: Yang dimaksud melayani anggotanya adalah memberi pelayanan usahanya kepada anggotanya dan bukan kepada masyarakat umum untuk mengedakan kebutuhan pokok, kebutuhan sarana produks itermasuk kredit dan bahan baku, serta pelayanan untuk memasarkan dan mendistribusikan hasil produksi anggota yang tidak mengakibatkan terjadinya praktek monopoli dan atau persaingan usaha tidak sehat.

${ }^{5}$ Undang-Undang No. 25 Tahun 1992, tentang Perkoperasin; Bab XII, Pasal 60 s/d Pasal 64. Pasal 60: (1) Pemerintah menciptakan dan mengembangkan iklim dan kondisi yang mendorong pertumbuhan serta pemasyarakat Koperasi; (2) Pemerintah memberikan bimbimgan, kemudahan, dan perlindungan kepada Koperasi. Pasal 61: Dalam upaya 
"mutlak". Pada akhirnya, karena koperasi tersebut merupakan badan-usaha yang dalam melaksanakan kegiatan usahanya menerapkan prinsip-prinsip ekonomi secara penuh, maka badan-usaha koperasi, pada suatu titik tetrtentu, tidak dapat menghindar dari menjalankan praktek bersaing secara ekonomi; hal ini dapat berlaku, dikarenakan: pertama, bahwa koperasi adalah merupakan sebuah badan-usaha, dan bukan merupakan badan sosial (dalam arti sekedar perkumpulan orang-orang); kemudian, kedua, bahwa usaha koperasi, adalah bebas, tergantung dari "kehendak" para anggota-nya, dalam arti menjalankan usaha-usaha yang bersifat ekonomis-praktis yang memberikan "keuntungan" bagi usaha dan anggota-nya...."

Pendahuluan ini kami sampaikan dengan dua-titik bahas: Pertama, tentang Prinsip Dasar Persaingan Usaha; dan Kedua, tentang Pembinaan Badan-Usaha Koperasi sebagai lembaga ekonomi rakyat yang keberadaannya di dalam konteks sistem perekonomian nasional.

\section{Pengertian Badan-Usaha Koperasi}

Untuk mengawali diskusi ini, ada baiknya terlebih dulu kami "mengajak" peserta diskusi untuk mengingat kembali tentang pengertian terhadap kata "Koperasi" dalam konteks diskusi ini. Dari sudut etimologis, kata Koperasi, pada mula-nya berasal dari dua-kata dalam bahasa latin, yaitu

menciptakan dan mengembangkan iklim dan kondisi yang mendorong pertumbuhan dab pemasyarakatan Koperasi, Pemerintah: a. memberikan kesempatan usaha yang seluas-luasnya kepada Koperasi; b. meningkatkan dan memantapkan kemempuan Koperasi agar menjadi Koperasi yang sehat dan mandiri; c. mengupayakan tata-hubungan-usaha yang saling menguntungkan antara Koperasi dengan badan usaha lain-nya; d. membudayakan Koperasi dalam masyarakat. Pasal 62: Dalam rangka memberikan bimbingan dan kemudahan kepada Koperasi, Pemerintah: a. membimbing usaha Koperasi yang sesuai dengan kepentingan ekonomi anggota-nya; b. mendorong, mengembangkan, dan membantu pelaksanaan pendidikan, pelatihan, penyuluhan, dan penelitian Koperasi; c. memberikan kemudahan untuk memperkokoh pemodalan Koperasi serta mengembangkan lembaga keuangan koperasi; d. membantu pengembangan jaringan usaha Koperasi dan kerjasama saling menguntungkan antara Koperasi; e. memberikan bantuan konsultasi guna memecahkan permasalahan yang dihadapi oleh Koperasi dengan tetap memperhatikan Anggaran dasar dan prinsip Koperasi. Pasal 63: (1) Dalam rangka pemberian perlindungan kepada Koperasi, Pemerintah dapat: a. menetapkan bidang kegiatan ekonomi yang hanya boleh diusahakan oleh Koperasi; b. menetapkan bidang kegiatan ekonomi di suatu wilayah yang telah berhasil diusahakan oleh Koperasi untuk tidak diusahakan oleh badan-usaha lain-nya. (2) Persyaratan dan tatacara pelaksanaan sebagaimana dimaksud dalam ayat (1) diatur lebih lanjut dengan Peraturan Pemerintah. Pasal 64: Pembinaan sebagaimana dimaksud dalam Pasal 60, Pasal 61, Pasal 62, dan Pasal 63 dilakukan dengan memperhatikan keadaan dan kepentingan ekonomi nasional, serta pemerataan kesempatan berusaha dan kesempatan kerja. 
Cum dan Aperari; yang berarti: "dengan bekerjasama". Kemudian, dua-kata dalam bahasa Latin tersebut di adopted di dalam bahasa Inggris menjadi duakata juga, yaitu: Co dan Operation; yang kemudian menjadi Cooperative, yang berarti, "beroperasi bersama-sama". Selanjutnya, dalam bahasa Belanda, disebut dengan istilah Cooperative Verenegingen; yang berarti: "bekerjasama dengan orang lain untuk mencapai suatu tujuan tertentu"7.

Dalam pengertian bahasa Indonesia, sekarang ini, kata Koperasi, membawa pengertian kepada sebuah lembaga organisasi-ekonomi; dengan beranggotakan orang-orang yang mempunyai kepentingan ekonomi yang sama, yang sifatnya "sukarela". Sehingga dapat kita simpulkan menjadi rangkaian kalimat, ..."Koperasi, adalah suatu Perkumpulan atau organisasi ekonomi yang beranggotakan orang-orang atau badan-badan usaha (koperasi) yang anggotanya bebas untuk keluar-masuk sebagai anggota, melakukan kerjasama secara kekeluargaan dalam lingkup ketentuan yang mereka buat sendiri berdasarkan ketentuan yang berlaku, untuk mencapai tujuan yang mereka rumuskan secara bersama-sama pula"s.

Dengan demikian, pengertian Badan-Usaha Koperasi, lebih jauh dapat diartikan sebagai salah satu dari "kendaraan" usaha yang dibentuk oleh para pendiri dan anggota dari sebuah perkumpulan Koperasi untuk melaksanakan kegiatan usaha-nya?.

${ }^{6}$ Azas Bekerjasama ini sebetulnya telah merupakan karakter dan sifat rakyat dan bangsa Indonesia yang kita kenal dengan istilah "gotong-royong". Sifat kegotong-royongan ini sebetulnya sudah cocok dengan perkumpulan dan organisasi badan-usaha koperasi; sehingga dalam pengertian filosofi hidup bangsa Indonesia dapat menjadi dasar yang kokoh dalam berkoperasi. Sedangkan azas Kekeluargaan seperti yang tercantum dalam Pasal 33 dari Konstitusi kita (UUD'45 dan Revisi) juga menjadi dasar kokoh untuk berkoperasi.

${ }^{7}$ R.T. Sutantya Rahardja Hadikusuma, "Hukum Koperasi Indonesia", (Jakarta: PT. Raja Grafindo Persada, 2000), hal. 1.

${ }^{8}$ Bandingkan dengan Pengertian Koperasi dalam Undang-Undang No. 25, tentang Perkoperasian, khususnya Pasal 1 ayat (1) sampai dengan ayat (5).

9 Bandingkan, Kwik Kian Gie, MPR dan Ekonomi Kerakyatan, Kompas, 16 Nopember 1998, hal.4., ..."koperasi adalah wadah yang tepat untuk memajukan perekonomian dari sekelompok orang-orang yang tidak mempunyai apa-apa, kecuali kebersamaan. Maka masuklah koperasi di dalam rumusan dan penjelasan Pasal 33 UUD $1945 \ldots .$. 


\section{Dasar-Hukum, Fungsi dan Tujuan Badan-Usaha Koperasi}

\section{A. Dasar Hukum}

Sebagaimana kami sebut dalam Pengantar makalah ini, dasarhukum lembaga Koperasi di Indonesia adalah Konstitusi Negara, UUD $1945^{10}$. Untuk itu, dalam penjelasan Konstitusi tersebut secara gamblang dapat dibaca, bahwa sistim ekonomi Indonesia didasarkan pada "asa" Demokrasi Ekonomi, dimana produksi dilakukan oleh semua dan untuk semua yang wujudnya dapat ditafsirkan sebagai Koperasi". Jadi, tidak ada dasar untuk menggunakan "asas kekeluargaan" ini dapat dijadikan sebagai pijakan untuk membentuk kroni ekonomi dari sebuah keluarga atau dengan bahasa popular sekarang, disebut Monopoli-Ekonomi oleh satu kroni keluarga..

${ }^{10}$ Pasal 33 UUD'45, ayat (3). Penjelasan Pasal ini secara jelas menyebutkan, bahwa, ... "bangun usaha yang paling cocok dengan azas kekeluargaan adalah Koperasi". Sebagai informasi tambahan, kami menemukan bahwa kalimat yang berbunyi ..."Perekonomian disusun sebagai usaha bersama berdasarkan azas kekeluargaan"...., pernah menjadi kontroversi pada awal era-reformasi, paska rezim administrasi Presiden Soeharto. Dalam kaitannya dengan Amandemen UUD'45, dosen Hukum Tata Negara dari FH-UI, Jimly Asshiddiqie, memberikan komentarnya sebagai berikut, ..."bahwa usul penghapusan perkataan "asas kekeluargaan" dari Pasal 33 UUD' 45 telah menimbulkan kontroversi yang sengit diantara para ahli yang juga memberi masukkan kepada anggota legislatip yang menjadi Badan Pekerja MPR. Golongan yang berkeinginan menghapuskan perkataan 'asas kekeluargaan', menganggap dua-kata ini telah disalahgunakan dalam praktek "monopoli" ekonomi oleh suatu keluarga; dengan berpijak pada terbentuknya kelompok penguasaan sector ekonomi yang terpusat pada satu keluarga (Presiden Soeharto). Pendapat ini tidak diterima oleh kelompok lain, yang melihat latar-belakang sejarah pembentukan UUD'45; ... idealisme konsep 'asa kekeluargaan' tidak boleh diartikan secara sempit dengan dikacaukan dengan realitas yang ada dalam praktek 'yang salah'. Karena, banyak factor penyebab dari tumbuhnya praktek kolusi, persekongkolan, sehingga tidak adil jika konsep 'asas kekeluargaan' yang dipersalahkan...."

"Isi dan inti dari Penjelasan tersebut, dituangkan (kembali) langsung dalam Amandemen ke-empat UUD'45; dimuat dalam ketentuan Pasal 33 ayat (4); berbunyi, ..."Perekonomian Nasional, diselenggarakan berdasarkan asas demokrasi ekonomi dengan prinsip kebersamaan, efisiensi, berkeadilan, berkelanjutan, berwawasan lingkungan, kemandirian, serta dengan menjaga keseimbangan kemajuan dan kesatuan ekonomi nasional".... Bandingkan dan lihat, Jimly Asshidigie, Konsolidasi Naskah UUD 1945 Setelah Perubahan Ke-empat, Pusat Studi Hukum Tata-Negara FHUI, Tahun 2002, hal. 55., ..."bahwa, dicantumkannya prinsip-prinsip kebersamaan, efisiensi, berkeadilan, berkelanjutan, berwawasan lingkungan, kemandirian, serta dengan menjaga keseimbangan kemajuan dan kesatuan ekonomi nasional, dalam ayat ini, adalah merupakan jalan-tengah dalam rangka melengkapi ketentuan ayat ( 10 yang berisikan 'asas kekeluargaan' yang menjadi kontroversial di masyarakat, akibat adanya usul dan isu "penghapusan". 
Kemudian, Koperasi di Indonesia mempunyai dasar hukum kedua, dalam bentuk Undang-Undang ${ }^{12}$; sehingga dengan dasar: Konstitusi dan Undang-Undang tersebut, kedudukan Koperasi di Indonesia mempunyai pijakan-hukum yang kokoh.

\section{B. Fungsi dan Tujuan Koperasi}

Fungsi Koperasi, menurut Mohammad Hatta, dalam pidato-radio yang berjudul Membangun Koperasi dan Koperasi Membangun, ${ }^{13}$, antara lain mengatakan, ..."bahwa Koperasi menurut waktu, tempat, dan keadaan, adalah meliputi tujuh-hal, yaitu: pertama, memperbanyak produksi; kedua, memperbaiki kwalitas barang; ketiga, memperbaiki distribusi; keempat, memperbaiki harga; kelima, menyingkirkan penghisapan dari lintah darat; keenam, memperkuat pemaduan capital; ketujuh, memelihara lumbung simpanan padi...." Dari semua tujuh-hal tersebut, dalam kurun waktu abad milinium ini ternyata masih tetap relevan; terutama dari sudut ketahanan ekonomirakyat dengan menggunakan badan-usaha Koperasi sebagai wadah dan kendaraan untuk menjalankan usaha. Sehingga, jika tujuh-hal tersebut dijalankan secara konsekwen dalam berkoperasi, bukan mustahil, Koperasi yang telah banyak berdiri di seluruh wilayah Indonesia ini, dapat berfungsi sebagai 'kendaraan' dan 'wadah' berkumpul para anggotanya dalam meningkatkan taraf kehidupan ekonomi mereka. ${ }^{14}$

Dalam hal berbicara mengenai Tujuan-Koperasi, maka tidak lain untuk menjalankan fungsi-nya sendiri yang dapat digambarkan sebagai berikut:

Pertama, Menjadi "kendaraan" bagi para anggota-nya untuk meningkatkan baik penghasilan maupun status ekonomi dalam lingkup kebersamaan dengan berorganisasi. Misalnya, menjadi anggota di

${ }^{12}$ Undang-Undang No.25 Tahun 1992, tentang Perkoperasian, Lembaran Negara Republik Indonesia Tahun 1992 Nomor 116., Tambahan lembaran Negara republic Indonesia Nomor 3502.

${ }^{13}$ Pidato Radio tersebut diucapkan dalam rangka memperingati Hari-Koperasi, 12 Juli Tahun 1951, Lihat selanjutnya Buku Kumpulan Pidato I, Mohammad Hatta, "Satu Abad Bung Hatta", (Jakarta: Gunung Agung, 2002).

${ }^{14}$ Pasal 3 UU No.25 Tahun 1992 tentang Koperasi, menyebut ide tersebut secara jelas; bahwa tujuan koperasi adalah ..."Memajukan kesejahteraan anggota pada khususnya dan masyarakat pada umumnya serta ikut membengun tatanan perekonomian nasional dalam rangka mewujudkan masyarakat yang maju, ...." 
sebuah Koperasi Unit Desa (KUD); para anggota tersebut menjual semua hasil produksi-pertaniannya, dan sebaliknya KUD melayani anggota-nya dengan menyediakan pupuk, bibit, alat pertanian, dan lain-lain kebutuhan pokok mapun produksi dari para anggota. KUD sebagai "kendaraan" para anggota, dapat menjual kepada para konsumen atau lembaga stok nasional seperti Bulog (Badan Urusan Logistik) atau Dolog (Depot-Logistik). Dengan "kendaraan" tersebut, para anggota paling tidak telah telah mempunyai "lembaga" sendiri, sehingga masing-masing anggota tidak perlu lagi berhubungan dengan tengkulak atau pedagang pengumpul lainnya. Karena Bulog atau Dolog adalah lembaga yang dibentuk Pemerintah untuk menjamin kebutuhan para petani produsen maupun konsumen, maka harga beli maupun harga jual dapat terukur dan tidak membuat para petani dan anggota Koperasi menjadi sengsara; dalam arti penghasilannya dapat lebih baik dibanding mereka berhubungan dengan para tengkulak; Kedua, sebagai lembaga, Koperasi dapat pula menyerap tenagaterampil baik dari segi administrasi maupun teknis, untuk bekerja mengurus dan menjalankan Koperasi; dalam arti dapat turut "menampung" tenaga kerja yang belum bekerja atau pengangguran; Ketiga, Menjadi tempat berkumpul dan berorganisasi dalam menjalankan kegiatan-ekonomi; disini, para anggota-nya dapat dilatih dan berlatih berorganisasi untuk mencapai tujuan mereka dalam bidang memenuhi kebutuhan ekonomi serta meningkatkan kemampuan ekonomi mereka sendiri baik secara individual maupun secara bersama-sama atau kelompok. Kemudian, Ke-empat, dapat dijadikan tempat mendidik para anggotanya dalam berorganisasi di bidang ekonomi dengan melakukan "perjuangan" untuk meningkatkan kesejahteraan-ekonomi mereka; selanjutnya, kelima, Koperasi dapat menjadi tempat "mendidik" para anggotanya menjalankan "demokrasi" dalam menjalankan organisasi ekonomi di sebuah Koperasi ${ }^{15}$. Dengan demikian, dalam "organisasi" lembaga Koperasi tersebut, para anggota dapat diberi informasi mengenai "demokrasi-

${ }^{15}$ Dalam tingkat seperti ini, Koperasi telah menjalankan fungsinya untuk menjadi tempat "mendidik" rakyat mengalami sendiri bagaimana menjalankan organisasi untuk kepentingan mereka sendiri; dengan demikian secara didak langsung mereka menjadi paham akan "menjalankan-usaha" dalam sebuah wadah, guna menjaga dan meningkatkan kepentingan ekonomi mereka, paling tidak. Tugas pemerintah, yang harus selalu konsekwen dan benar dalam menjalankan perannya menjalankan ekonomi-rakyat; agar dari waktu ke waktu menjadi baik dan baik. Selanjutnya dapat dibandingkan dengan pendapat Hadikusuma dalam R.T. Sutantya Raharja Hadikusuma, "Hukum Koperasi Indonesia", (Jakarta, Grafindo Persada. 2000), hal. 40-44. 
ekonomi" dalam ekonomi-kerakyatan dimana dapat menjadi "wadah" untuk "berlindung" dan "menghindar" dari sistim perekonomian yang berdasarkan "modal-kuat"16.

Dari lima-fungsi diatas dapat kita persempit lagi, bahwa lembaga Koperasi tersebut sangat bermanfaat dan cocok untuk kondisi ekonomi rakyat Indonesia yang mayoritas tinggal di pedesaan dan hidup dari bertani dengan segala turunan-nya. Lembaga Koperasi dapat menjadi wadah yang menlindungi kepentingan kehidupan perekonomian dan ekonomi rakyat; sekaligus keberadaan-nya berfungsi sebagai "penyeimbang" dari dominasi pemilik modal-kuat yang hanya menjadikan rakyat sebagai salah satu faktor produksi dan industri mereka.

Karena kedudukan lembaga Koperasi ${ }^{17}$ ini dalam lingkup kehidupan rakyat yang tergolong "modal-lemah", maka logis jika

16 Dari sejarah bangsa (Hindia-Belanda), rakyat telah "mengalaminya" sendiri, bahwa sistim perekonomian yang hanya didasarkan "modal-kuat" di sebuah Negara, tidak pernah memberikan kesempatan kepada rakyat-banyak (yang tidak memiliki modal) untuk dapat bangkit dari kemiskinan dan kekurangan dalam ukuran ekonomi. Kelompok ekonomi "modal-kuat", umum-nya menjalankan Free Fight Leberalism, yang menimbulkan eksploitasi terhadap rakyat; karena rakyat hanya menjadi faktor produksi. Kemudian, terjadi Etatism, dimana Negara berserta aparatur-nya menjadi dominan dan "pelindung" dari pemilik Modal; akibatnya, kreasi dan kreatifitas potensi rakyat didalam kegiatan-ekonomi dan berada diluar sektor Negara "dimatikan"; kemudian akan terus berujung ke arah Monopoli; yang merugikan rakyat.

${ }^{17}$ Lembaga Koperasi mempunyai Prinsip-Prinsip sendiri disamping itu sebagai lembaga ekonomi yang mempunyai prinsip tersediri pula. Pada dasarnya, Prinsip-Koperasi adalah tolong-menolong dengan nilai-nilai: a.l., menolong diri-sendiri, tanggung-jawab pribadi, demokrasi, persamaan, keadilan, dan kesetiakawanan. Semua ini harus didukung oleh etika-moral para anggotanya yang berupa a.l., kejujuran, keterbukaan, tanggung-jawab sosial dan rasa peduli terhadap orang lain. Bandingkan dengan Prinsip-Koperasi yang diformulakan oleh lembaga koperasi Internasional atau ICA (International Cooperative Alliance) di Manchester, Inggeris pada tahun 1995, a.l., meliputi: (1). Prinsip keanggotaan yang sukarela dan terbuka; (2). Prinsip Pengawasan oleh anggota, secara demokratis; (3). Prinsip-Partisipasi para anggota dalam kegiatan-ekonomi; (4). Prinsip Ekonomi dan Kemandirian; (5). Prinsip Pendidikan, pelatihan, dan Informasi; (6). Prinsip-Kerjasama antar Koperasi; dan, (7). Prinsip Kepedulian terhadap Masyarakat. Selanjutnya dapat dibandingkan dengan Prinsip-Prinsip Koperasi Indonesia yang tertulis dalam Undang-Undang No.5 Tahun 1992, tentang perkoperasian: a.l., pertama, keanggotaan bersifat sukarela dan terbuka; kedua, Pengelolaan dilakukan secara demokratis; ketiga, Pembagian sisa hasil-usaha dilakukan secara adil sebanding dengan besarnya jasa dari masing-masing anggota; ke-empat, Pemberian balas jasa yang terbatas terhadap modal; kelima, kemandirian; ke-enam, Pendidikan Perkoperasian; dan ketujuh, Kerjasama antar Koperasi. Selanjutnya Lihat Lembaga Pendidikan Perkoperasian (Lapenkop) Bukopin, Lebih Mengenai Koperasi, (Bandung: Lapenkop Bukopin), hal. 8-15. 
keberadaan-nya "dalam-lindungan" Negara dan Pemerintah. Walaupun demikian, secara utuh, lembaga Koperasi tersebut adalah merupakan lembaga ekonomi dalam arti dimata hukum harus didudukkan sebagai Badan-Usaha yang berstatus Badan-Hukum; sehingga keberadaannya satu level dengan Badan-Bandan Usaha yang ada di Negara Indonesia.

\section{Persaingan Usaha Yang Sehat dan Usaha - Koperasi}

\section{A. Dasar-Hukum Persaingan Usaha Yang Sehat}

Perekonomian Negara Indonesia yang dijalankan berdasarkan sistim demokrasi ekonomi, seyogyanya selalu menjaga "keseimbangan" antara "kepentingan" para pelaku kegiatan ekonomi dan "kepentingan umum"; artinya persaingan usaha yang terjadi antara mereka harus dilakukan secara sehat dan tidak ada satu pihakpun diantara mereka itu yang dapat ditolerir jika melakukan perbuatan "curang". Berbuat "curang" dalam pengertian Persaingan Usaha yang Sehat, diartikan sebagai: ...tidak membuat kartel atau "persekongkolan" untuk menguasai suatu sektor produksi tertentu atau sebuah wilayah pangsa pasar tertentu dengan memonopoli. Sebagai ilustrasi, dapat kita lihat kasus Microsoft Corporation di Pengadilan Distrik Negara bagian Columbia ${ }^{18}$.

Dalam kasus Microfoft tersebut di atas, Pemerintah Amerika Serikat telah bertindak secara hukum terhadap ("mencegah") terjadinya perbuatan curang dan praktek monopoli dengan melaksanakan ketentuan-hukum yang mengatur tentang perbuatan Praktek Monopoli di Negara tersebut. Dengan adanya Ketentuan tersebut, Pemerintah secara formal kenegaraan mempunyai

18 Kasus antara Pemerintah Amerika Serikat melawan Microsoft Corporation; dimana Microsoft telah dituduh melakukan tindakan Monopoli untuk maksud menguasai pasar perangkat-lunak computer di wilayah Amerika Serikat. Kasus ini dapat menunjukkan kepada kita bahwa dalam mencegah praktek monopoli, Pemerintah dapat melakukan kontrol dan membuat kebijakan untuk mencegah secara proaktip setiap kemungkinan atau gejala adanya perbuatan praktek monopoli. Sebagai bahan perbandingan dapat dibaca artikel M. Doddy Kusadrianto, Menciptakan Persaingan Usaha Yang Sehat Melalui Penerapan Prinsip "Good Corporate Governance", disitu dikatakan... "Tidak dapat dipungkiri bahwa salah satu elemen terpenting dalam terciptanya iklim persaingan usaha yang sehat sangat tergantung kepada efektifitas penerapan nilai-nilai atau prinsip pengelolaan perusahaan yang baik ...." ; Forum for Corporate in Indonesia (FCGI), <http://www.fcgi.or.id>, diakses pada tgl 12 Nopember 2004. 
kewenangan (berdasarkan hukum) untuk mengambil kebijakan (policy-making) dan sekaligus melaksanakan kebijaksanaan (policyexecuting) dalam mencegah dan mengantisipasi kemungkinan terjadinya monopoli dan persaingan tidak sehat ${ }^{19}$.

Di Indonesia dewasa ini, dengan adanya Ketentuan Larangan Praktek Monopoli dan Persaingan Usaha yang Tidak Sehat ${ }^{20}$, Pemerintah R.I. secara proaktip dapat bertindak sama seperti Pemerintah Amerika Serikat terhadap kasus seperti Microsoft tersebut. Ini berarti, pemerintah Republik Indonesia telah mempunyai landasanhukum untuk membuat dan menjalankan kebijakaan terhadap perbuatan Praktek Monopoli dan Persaingan yang Tidak sehat; perbuatan mana jelas dapat merugikan rakyat secara keseluruhanan. Dengan dasar ini pula Pemerintah R.I. membutuhkan sebuah lembaga yang dapat melakukan pengawasan, pengontrolan, dan dapat melakukan tindakan-hukum terhadap setiap adanya praktek Monopoli tersebut; sekarang ini bentuknya sebagai sebuah Komisi yang disebut Komisi Pengawas Persaingan Usaha (KPPU) ${ }^{21}$.

Keberadaan Undang-Undang tersebut di atas, secara-hukum telah melengkapi dan memperkuat amanat konstitusi Negara ${ }^{22}$ yang "melindungi" pelaku ekonomi yang lemah dalam hal modal. Dengan adanya kesempatan berusaha dan mendapat jaminan perlindungan dari Negara tersebut, kelompok ekonomi yang bermodal lemah dapat turut serta melakukan usaha-nya dengan bersaing secara wajar; dengan demikian memberi peluang kepada berkembangnya ekonomi kerakyatan ${ }^{23}$.

19 Bandingkan dengan Undang-Undang No.5 Tahun 1999, dalam Konsiderans Menimbang huruf c, yang tertulis sebagai berikut: ..." setiap orang yang ber-usaha di Indonesia harus berada dalam situasi persaingan yang sehat dan wajar, sehingga tidak menimbulkan adanya pemusatan kekuatan-ekonomi pada pelaku usaha tertentu, dengan tidak terlepas dari kesepakatan yang telah dilaksanakan oleh negara republic Indonesia terhadap perjanjian-perjanjian Internasional".

${ }^{20}$ Undang-Undang No.5 Tahun 1999, Lembaran Negara R.I. Tahun 1999 Nomor 33, Tambahan LN-RI Tahun 1999, Nomor 3817.

21 Undang-Undang No.5 Tahun 1999, Pasal 1 angka (9)., Pengertian Komisi Persaingan Usaha adalah: Komisi yang dibentuk untuk mengawasi pelaku usaha dalam menjalankan kegiatan usaha-nya.

${ }^{22}$ Undang-Undang Dasar 1945, Pasal 27 ayat (2), yang tertulis sebagai berikut: .."setiap orang berhak atas kehidupan yang layak". 
Dalam realitas sehari-hari, kegiatan di dalam dunia-usaha, adanya persaingan harus dipandang dari sudut positip. Arinya, Konsep Persaingan-Usaha (yang sehat) harus dibaca dalam konteks potensi melahirkan usahawan-usahawan yang kuat yang mampu dan tangguhbersaing karena menjalankan usaha-nya secara efisien. Mereka mampu menggali kreatifitas dalam memproduksi maupun memberikan pelayanan yang berkwalitas (awal mapun dalam era purna jual). Sampai pada titik ini, Konsumen juga pada akhirnya mendapat untung; dalam arti mendapat produk yang bermutu tinggi dan pelayanan purnajual yang baik. Dengan demikian, baik jaminan mutu, pelayanan, dan lain sebagainya, secara-hukum dan bisnis dapat dipertanggung-jawab $\operatorname{kan}^{24}$.

\section{B. Keberadaan Badan-Usaha Koperasi dalam Perekonomian Indonesia}

Keberadaan badan-usaha Koperasi di wilayah negara Indonesia, tercantum didalam Konstitusi Negara Republik Indonesia; dengan demikian, eksistensinya dijamin oleh Konstitusi ${ }^{25}$. Dalam memandang eksistensi badan-usaha Koperasi ini penyusun meminjam pendapat

${ }^{23}$ Lihat Mubiarto, Artikel Th.I-No.6 Agustus 2002., Membangkitkan Ekonomi Kerakyatan Melalui Gerakan Koperasi., Peran Perguruan Tinggi., ..."Ekonomi Rakyat, adalah usaha ekonomi yang tegas-tegas tidak mengejar keuntungan tunai, tetapi dilaksanakan untuk (sekedar) memperoleh pendapatan bagi pemenuhan kebutuhan keluarga secara langsung dalam hal pangan, sandang, papan, dan kebutuhan-kebutuhan keluarga lainnya dalam arti luas; yang semua-nya mendesak dipenuhi dalam rangka pelaksanaan pekerjaan pokok anggota..." dikatakan juga bahwa Ekonomi-Rakyat dalam arti luas adalah, ..."mencakup kehidupan petani, nelayan, tukang becak, dan pedagang kecil seperti pedagang kaki-lima; yang kepentingan-kepentingan ekonominya selalu dapat lebih mudah dibantu atau diperjuangkan melalui Koperasi..." < http:www.ekonomi.org/edisirakyat_6/artikel_3htm>, diakses pada 12 Nopember 2004. Bandingakan dan Lihat, Ketetapam MPR No.16/MPR/1998 tentang Politik Ekonomi dalam rangka Demokrasi Ekonomi, yang popular dengan sebutan EkonomiKerakyatan.

${ }^{24}$ Tujuan Pemerintah secara Proaktip melakukan pengawasan lewat KPPU, adalah tidak lain untu: pertama, menjamin agar hak bagi setiap individu dapat tetap terwujud dan eksploitasi dapat dihindarkan; kedua, menjaga perekonomian dapat tumbuh dan mengalami perkembangan yang teratur dan stabil; ketiga, mengawasi pelaku-usaha dan kegiatankegiatannya tidak melanggar ketentuan laranganan tentang Praktek Monopoli; keempat, mencegah hal-hal yang dapat merugikan masyarakat baik secara ekonomis, sosiologis, maupun pilosofis., lihat Banu Muhammad, dalam Hukum Persaingan Usaha di Indonesia, Aspek Ekonomi dari Hukum-Persaingan Usaha, Lembaga Kajian dan Kebijakan Usaha, FHUI, Tahun 2003, hal. 11-12.

${ }^{25}$ Undang-Undang Dasar 1945, Pasal 33. 
Prof. Mubyarto yang mengatakan bahwa, ..."secara teoritis, ilmuekonomi diberi definisi sebagai suatu sistim yang menggambarkan perikehidupan manusia sehari-hari; dalam rangka usahanya untuk memenuhi kebutuhan hidupnya...."26

Sebagaimana kita alami sehari-hari, bahwa "kebutuhan" yang disebut Mubyarto ini dalam konteks dan lingkup aspek material, aspek moral, maupun aspek sosial-budaya ${ }^{27}$. Selanjutnya, dalam kesempatan lain Mubyarto di tahun 1989, menyebutkan bahwa di Indonesia dikenal ada tiga kelompok organisasi-ekonomi atau badan-usaha, yaitu: Pertama, sektor ekonomi-negara; yang berorientasi pada pelayanan kepada kepentingan-umum dan rakyat-banyak; Kedua, sektor ekonomi-swasta; yang berorientasi pada menjalankan usaha untuk memupuk keuntungan-maksimal; Ketiga, sektor ekonomiKoperasi, yang berorientasi pada kerjasama dengan asas kekeluargaan, untuk memperjuangkan dan memajukan tingkat perekonomian para anggota-nya ${ }^{28} \ldots . "$

Dalam kehidupan sehari-hari, pembagian atas tiga-sektor perekonomia di atas belum dapat memberikan ruang kepada sektorinformal lainnya yang tidak terdaftar; seperti usaha kecil "pedagang kaki-lima (PKL)" atau usaha kecil lainnya yang secara fakta memberikan tempat kepada "geliat" aktifitas-ekonomi riel yang dilakukan oleh mayoritas rakyat-kecil dewasa ini. Sektor-sektor perekonomian informal ini, -dilihat secara holistik dalam praktek-, saling melengkapi satu sama-lainnya; dimana mereka ternyata 1987), hal. 22.

${ }^{26}$ Mubyarto, "Ekonomi Pancasila: Gagasan dan Kemungkinan", (Jakarta: LP3ES,

27 Dengan melihat aspek-aspek tersebut, Mubyarto membuat Konsep mengenai Ekonomi-Pancasila. Menurut pendapat beliau, Ekonomi Pancasila, adalah sistim-ekonomi atau sistim-perekonomian yang dianut dan dijalankan oleh Bangsa dan Negara Indonesia yang berbeda dengan sistim-ekonomi Kapitalis maupun sistim-ekonomi Komunis; karena dijiwai oleh ideologi-Pancasila: yaitu sitim-ekonomi yang didasari oleh usaha-bersama yang berasaskan "kekeluargaan" dan semangat Gotong-Royong. Dengan demikian, sistim-ekonomi Pancasila, mempunyai lima-ciri pokok yang disebutnya cirri-khas, yaitu: pertama, Koperasi, merupakan soko-guru perekonomian; kedua, digerakkan oleh rangsangan ekonomi, sosial, dan berbasis pada moral; ketiga, merupakan kehendak dari seluruh masyarakat kea rah keadaan kemerataan sosial, egaliterisme; keempat, prioritas kebijakan-ekonomi adalah menciptakan perekonomian nasional yang tangguh; kelima, adanya keseimbangan yang tegas antara perencanaan nasional dengan tekanan pada desentralisasi dalam pelaksanaan kegiatankegiatan enonomi. Ibid., hal. 32-42.

${ }^{28}$ Teddy Pawitra (ed.), "Manajemen di Indonesia; Beberapa Isu Kontemporer", (Jakarta: Lembaga Penerbit FE-UI, 1993), hal. 89. 
merupakan -derivative- kesatuan dalam sistim-ekonomi bersekalabesar maupun bersekala-kecil ${ }^{29}$.

Dengan demikian, adanya usaha-besar dan usaha-kecil yang mempunyai porsi-usaha masing-masing ternyata dapat hidup bersama, berdampingan dan saling melengkapi ${ }^{30}$. Banyak contoh-contoh lain yang dapat kita temukan sehari-hari di sekeliling kehidupan kita dengan masing-masing fungsinya sehingga secara holistik merupakan "kesatuan"; lebih jauh, dari sudut "berusaha", secara tidak sadar diantara mereka yang berada dalam kesatuan ini, dalam pengertian fungsionalisasi, telah menghasilkan "pemerataan" kesempatan untuk ber-usaha.

Berbicara mengenai fungsionalisasi, lembaga Koperasi dapat secara praktis menjadi wadah dan kendaraan untuk menuju ke "pemerataan" kesempatan berusaha. Mengenai apakah pemerataan kesempatan ini dapat dimanfaatkan secara maksimal oleh Koperasi, tergantung dari sukses atau tidak-nya para Pengurus Koperasi yang bersangkutan membangun jaringan-organisasi dan jaringan-bisnis secara luas dalam kurun waktu yang direncanakan. Kegagalan dalam membentuk dan membangun jaringan-usaha, membawa efek yang luas terhadap kelangsungan usaha dari Koperasi yang bersangkutan. Sehingga, dapat dikatakan bahwa "jaringan" yang kita bicarakan ini merupakan tolok-ukur dalam keberhasilan membentuk "kerjasama" yang saling menguntungkan antara Koperasi yang telah mapan usahanya dengan Koperasi-Koperasi yang masih lemah; atau secara luas jaringan-usaha dengan badan-usaha lain yang non-koperasi.

Dalam kaitannya dengan Pilar Ekonomi Nasional, maka falsafah yang dipakai sebagai dasar untuk membangun "jaringan" lembagalembaga badan-usaha Koperasi baik antara Koperasi yang bergerak dalam bidang usaha sejenis maupun yang tidak sejenis dan baik yang

${ }^{29}$ Teddy Pawiter (ed.), Ibid.. hal. 89-90.

${ }^{30}$ Contoh yang paling gampang dilihat sehari-hari adalah keberadaan usaha kecil kaki-lima (terutama yang berdagang makanan/warung makan) yang berada disekeliling gedung-gedung perkantoran atau mal-mal yang ada di Jakarta; usaha-kecil kaki-lima tersebut, ternyata sangat membantu para karyawan yang bekerja di dalam gedung-gedung perkantoran atau mal-mal itu misalnya dalam-hal "menyediakan" makan-siang atau makan-sore yang beragam. Mengapa warung-makan itu berfungsi? Tidak lain, harga panganan yang mereka jual dapat "terjangkau" dan sesual dengan "isi-kantong" para karyawan. Dengan demikian, yang perlu diperhatikan oleh pemerintah-setempat, adalah "Pengaturan dan Pengawasan" yang tegas, terutama menjaga kondisi tempat tersebut selalu bersih, sehat, dan tidak menjadi "kumuh" 
primer maupun sekunder, adalah: "kebersamaan" dan "saling percayamempercayai".

Dengan asumsi kondisi dan dengan situasi yang demikian dari sudut, "jaringan-pasar" yang terbentuk, dapat menjadi pengaruh nyata dalam pembentukan struktur pasar; dimana unsur-unsur dari tiga-pilar pasar: produsen, pedagang, dan konsumen "bertemu" dalam memenuhi kepentingan mereka masing-masing. Apakah akan terjadi "penguasaan" pasar; disinilah memerlukan sebuah sistim-pengaturan yang jelas dan "tindakan" yang tegas agar keberadaan tiga-unsur pasar tadi (selalu) dalam kondisi bersaing secara sehat.

\section{Konsep Persaingan-Usaha yang Sehat}

Konsep Persaingan-Usaha yang Sehat, berisi tiga-hal pokok sekaligus dijadikan objek yang "dilarang"; yang dijadikan "wilayah" untuk melihat: apakah ada persaingan usaha yang tidak sehat. Pertama, lingkup-kesepakatan, persekongkolan atau perjanjian; Kedua, lingkup-kegiatan; dan Ketiga, lingkup-dominasi.

Dewasa ini, tiga lingkup-wilayah tersebut telah terakomodasikan di dalam ketentuan perundang-undangan yang mengatur tentang Larangan Praktek Monopoli dan Persaingan Usaha Tidak Sehat. Prinsip-prinsip yang diatur dalam undang-undang ini, antara lain: Pertama, adalah lingkup Perjanjian yang Dilarang; a.l., yang meliputi: (1). Oligopoli ${ }^{31}$; (2). Penetapan Harga ${ }^{32}$; kemudian, (3).

${ }^{31}$ Lihat Komisi Pengawas Persaingan Usaha R.I (KPPU-RI)., dalam: UndangUndang No.5 Tahun 1999, KPPU-RI Copyright-2007, ., Pasal 4 ayat (1) dan ayat (2)., ayat (1), berbunyi, ... "Pelaku-usaha dilarang membuat perjanjian dengan pelaku-usaha lain untuk secara bersama-sama melakukan penguasaan produksi dan-atau pemasaran barang dan-atau jasa yang dapat mengakibatkan terjadi praktek monopoli dan-atau persaingan tidak sehat". Selanjutnya ayat (2) berbunyi, ... "... apabila 2 (dua) atau 3 (tiga) pelaku-usaha atau kelompok pelaku-usaha menguasai lebih dari $75 \%$ (tujuhpuluh lima persen) pangsa-pasar satu jenis barang atau jasa tertentu". Bandingkan dengan, Ditha Wiradiputra, dalam Hukum Persaingan Usaha di Indonesia: Perjanjian yang Dilarang., ... "Ologopoli itu sendiri merupakan salah satu struktur pasar dimana di dalam pasar tersebut hanya terdiri dari sedikit perusahaan. Setiap perusahaan yang ada di dalam pasar tersebut memiliki kekuatan yang (cukup) besar untuk mempengaruhi harga pasar dan perilaku setiap perusahaan akan mempengaruhi perilaku perusahaan lainnya dalam pasar., Lembaga Kajian Persaingan dan Kebijakan Usaha FHUI, tahun 2003, hal. 3-4.

${ }^{32}$ Lihat KPPU-RI, Ibid., lihat Pasal 5, 6, 7, 8., dan Bandingkan dengan Dhita Wiradiputra, Ibid., hal.5-11., ... "Bahwa Perjanjian Penetapan Harga yang dilarang oleh Undang-Undang ini, adalah: (1). Perjanjian Penetapan Harga (Price Fixing Agreement) yang merupakan suatu stratergi yang dilakukan oleh pelaku-usaha yang tujuannya adalah untuk 


\section{Pembagian Wilayah ${ }^{33}$; dan Pemboikotan ${ }^{34}$. Lebih lanjut, adalah: Kartel $^{35}$; kemudian berbentuk Trust $^{36}$., selanjutnya Ologopsoni ${ }^{37}$;}

menghasilakan laba yang setinggi-tingginya, dimana dengan adanya penetapan harga oleh pelaku-usaha (produsen/penjual) telah meniadakan persaingan dari segi harga terhadap produk yang mereka jual/pasarkan, dimana dapat mengakibatkan consumer's surplus ...."; selanjutnya, ... "(2). Perjanjian Diskriminasi Harga (Price Discrimination Agreement), perjian yang dibuat oleh pelaku-usaha dengan pelaku-usaha lain, dimana untuk satu produk yang sama dijual kepada konsumen satu dengan konsumen lain berbeda harga; tujuannya adalah untuk, meningkatkan laba yang setinggi-tingginya, dengan mengeksploitasi surpluskonsumen; (3). Harga Pemangsa (Predatory Price), adalah salah satu strtegi yang dilakukan oleh pelaku-usaha untuk menjual produk denga harga yang sangat rendah, dengan tujuan utamanya untuk menyingkirkan pelaku-usaha pesaingnya dari pasar dan juga mencegah pelaku-usaha yang berpotensi menjadi pesaing untuk masuk ke dalam pasar yang sama...."., kemudian (4). ResalepPrice Maintenance, yaitu: pelaku-usaha (umumnya manufaktur) dengan para penrusahaan penyalur, dimana ditentukan bahwa penerima barang tidak akan menjual kembali barang yang telah diterimanya kepada pihak lain dengan harga yang lebih rendah dari yang telah diperjanjikan, sehingga membuat pesaing di tingkat penyalur akan menjadi hilang.

33 Lihat KPPU-RI, Ibid., Pasal 9., kemudian, Bandingkan dengan Dhita Wiradiputra., Ibid., hal.12. yang mengatakan, ..."... dalam Pembagian Wilayah, pelaku-usaha membuat perjanjian dengan pelaku-usaha pesaingnya untuk membagi daerah atau wilayah pemasaran-nya, atau alokasi pasar mereka masing-masing. Hal ini merupakan salah satu strtegi yang dipakai oleh pelaku-usaha untuk menghindari terjadinya persaingan diantara mereka. Sehingga menreka dapat menguasai wilayah pemasaran atau alokasi pasar yang menjadi bagian-nya tanpa harus melalui persaingan...."

${ }^{34}$ Lihat KPPU-RI, Ibid., Pasal 10., dan Bandingkan dengan Dhita Wiradiputra, Ibid., hal.14. yang mengatakan, ..."bahwa Perjanjian Peboikotan merupakan salah satu strategi yang dilakukan diantara pelaku-usaha untuk mengusir pelaku usaha lain dari Pasar yang sama...., kemudian pasar tersebut terjaga hanya untuk kepentingan mereka sendiri. Wujud dari Perjanjian Pemboikotan, biasanya dalam bentuk persekongkolan yang menolak untuk memasarkan suatu produk dari pesaing mereka; sehingga produk pesaing tersebut tidak dapat atau sulit untuk dijual di pasar yang bersangkutan., ...."

${ }^{35}$ KPPU-RI, Ibid., Pasal 11., bandingkan dengan pendapat Dhita Wiradiputra, Ibid., hal. 15., ... "bahwa praktek Kartel... diterapkan diantara para pelaku-usaha untuk dapat mempengaruhi harga dengan mengatur jumlah produksi mereka, dengan asumsi, ...jika produk mereka di dalam pasar dikurangi sedang permintaan terhadap produk mereka tetap, maka ... harga terkerek ketingkat yang lebih tinggi., ...."

${ }^{36}$ KPPU-RI., Ibid., Pasal 12., dan Bandingkan juga dengan Dhita Wiradiputra, Ibid., hal.18., yang mengatakan, bahwa, ... "untuk dapat mengontrol produksi atau pemasaran produk di pasar, ... mereka membentuk gabungan perusahaan dalam bentuk "TRUST", ... dimaksudkan untuk secara kolektip mengendalikan pasokan...."

${ }^{37}$ KPPU-RI., Ibid., Pasal 13., dan Bandingkan dengan Dhita Wiradiputra, Ibid., hal. 18-19., yang mengatakan, bahwa, ..."dalam Oligopsoni, pelaku-usaha membuat kesepakatan dengan pelaku-usaha lain, ...secara bersama-sama dapat menguasai pembelian atau 
Lebih lanjut, ada Integrasi-Vertikal ${ }^{38}$; Perjanjian Tertutup ${ }^{39}$; dan Perjanjian dengan Pihak Luar-Negeri ${ }^{40}$.

Disamping lingkup Perjanjian yang Dilarang di atas, Kedua., adalah lingkup Kegiatan yang Dilarang. Dalam lingkup ini, ada 4 (empat) Kegiatan yang Dilarang, yaitu: (a). Kegiatan Monopoli' ${ }^{41}$; (b).Monopsoni ${ }^{42}$; (c). Penguasaan Pasar ${ }^{43}$; (d). Persekongkolan ${ }^{44}$.

permintaan pasokan agar dapat mengendalikan harga.... ", sehingga pembeli dalam cara ini menerima saja berapapun harga yang ditentukan karena tidak ada pilihan lain.

${ }^{38}$ KPPU-RI, Ibid., Pasal 14., dan Bandingkan juga dengan Dhita Wiradiputra, Ibid., hal. 19., yang mengatakan bahwa, ... "Ketika pelaku-usaha ingin agar pangsa pasar yang dimilikinya menjadi lebih besar, tingkat efisiensi semakin tinggi dan juga untuk mengurangi ketidakpastian akan pasokan bahan-baku, ... biasanya perusahaan akan menempuh jalan untuk melakukan penggabungan dengan pelaku-pelaku usaha lain yang mempunyai kelanjutan proses produksi"..., secara terintegrasi (integrasi-vertikal).

${ }^{39}$ KPPU-RI, Ibid., Pasal 15., Bandingkan juga dengan Dhita Wiradiputra., Ibid., hal 23., yang mengatakan bahwa, ... "Perjanjian Tertutup (Exclusive Distribution Agreement) adalah, pelaku-usaha membuat perjanjian dengan pelaku-usaha lain yang membuat persyaratan bahwa pihak penerima produk hanya akan memasok ..., ... hanya boleh memasok produk kepada phak tertentu saja...."

${ }^{40}$ KPPU-RI., Ibid., Pasal 16., yang berbunyi, ..."Pelaku-Usaha dilarang membuat perjanjian dengan pihak lain di luar-negeri yang memuat ketentuan yang dapat mengakibatkan terjadinya praktek monopoli dan-atau persaingan usaha tidak sehat".

${ }^{41}$ KPPU-RI., Ibid., Pasal 17., dan lihat lebih lanjut pada Gunawan Wijaya, dalam Merger dalam Perspektip Monopoli, PT Raja Grafindo Persada, Cet. Pertama, Jakarta, tahun 2002., hal.17-17., ... "bahwa ada beberapa monopoli yang secara alamiah dapat diakui, yaitu: a.l., (a). Monopoli yang terjadi akibat dari Superior Skill; wujudnya dapat dalam bentuk pemberian Hak-Paten secara eksklusif oleh Negara, berdasarkan Peraturan Perundangundangan yang berlaku, kepada pelaku-usaha tertentu atas hasil riset atau penemuan-ilmiah dan pengembangan teknologi tertentu.; (b). Monopoli terjadi karena pemberian Negara berdasarkan Peraturan Perundang-undangan aatu Konstitusi. Contohnya di Indonesia, berdasarkan Pasal 33 UUD 1945, ayat (2) dan ayat (3).; (c). Monopoli yang lahir karena latar belakang sejarah (Historical Accident); karena monopoli tersebut terjadi secara tidak-sengaja, dan berlangsung karena proses alamiah dan beberapa factor terkait...." Bandingkan dengan, Sri Edi Swasono (ed)., Mencari Bentuk, Posisi, dan Realitas: koperasidi dalam Orde Ekonomi Indonesia., UI Press, cet.Kedua, Jakarta, Tahun 1985, hal. 249., yang kutipan-nya a.l., ... "Ada yang mempertanyakan, mengapa kepada perusahaan-perusahaan Negara (BUMN) "diberikan" monopoli. Jawaban-nya, ada di dalam Konstitusi Negara kita. Koperasi dan perusahaan-negara "memiliki monopoli" itu tidak bertentangan dengan Demokrasi Ekonomi, karena kedua jenis badan-usaha itu adalah milik masyarakat, bukan milik orang-perorangan.... Oleh karena itu tidak tepat menyamaratakan monopoli oleh Negara dengan monopoli oleh Swasta...."

${ }^{42}$ KPPU-RI., Ibid., Pasal 18. Monopsony dalam istilah hukum didefinisikan sebagai, ... is a condition of market in which, there is but one-buyer for a particular commodity. 
Selanjutnya Ketiga, adalah mengenai Posisi Dominan yang meliputi: (a). Jabatan Rangkap ${ }^{45}$, (b). Pemilikan Saham ${ }^{46}$, (c). Penggabungan, peleburan dan pengambilalihan ${ }^{47}$.

Ada dua instrumen yang lazim dipakai dalam menentukan kebijakan untuk mengatur tentang Persaingan-Usaha; instrumen pertama, Kebijakan Struktural, dan instrumen kedua, Kebijakan perilaku ${ }^{48}$. Dua kebijakana yang dijadikan instrumen untuk "mengatur" jalur perasingan sehat tersebut apabila diterapkan dalam praktek dapat saja mendistorsi kegiatan usaha. Padahal, dalam keadaan situasi pasar seimbang, dimana posisi konsumen dan produsen berkedudukan sama dalam arti seimbang, maka sebetulnya persaingan usaha yang sehat akan terjadi dengan sendirinya. Dengan demikian, yang perlu dijaga dan diciptakan adalah situasi keseimbangan antara posisi kepentingan dari dua pihak di atas. Selanjutnya, apabila keseimbangan ini dapat tetap dijaga, maka para produsen dan konsumen sendiri yang akan memetik keuntungannya; dan khusus untuk produsen, adanya persaingan usaha yang sehat tersebut mendorong kondisi pasar tetap terjaga seimbang.

Jadi, Konsep Persaingan-Usaha yang Sehat yang diatur di dalam UU No.5 Tahun 1999 itu adalah menjaga harmonisasi atau keseimbangan antara para produsen (termasuk: distributor dan para pedagangnya) dengan konsumen. Khusus untuk Produsen, adanya konsep persaingan-usaha yang sehat dapat dijadikan faktor "pendorong" untuk lebih berprestasi dalam hal: kwalitas, kreativitas, pelayanan, dan efisiensi. Sedangkan untuk Konsumen, keuntungannya adalah adanya jaminan dari produsen dalam hal: kwalitas, tersedia pelayanan yang baik, serta harga pantas yang sesuai dengan kwalitas.

\footnotetext{
${ }^{43}$ KPPU-RI., Ibid., Pasal 19-21.

${ }^{44}$ KPPU-RI., Ibid., Pasal 22-24.

${ }^{45}$ UU No.5 tahun 1999, Ibid., Pasal 26.

${ }^{46}$ UU No.5 tahun 1999, Ibid., Pasal 27.

${ }^{47}$ UU No.5 tahun 1999, Ibid., Pasal 28.

${ }^{48}$ Ronny Bako, Tinjauan Yuridis atas Keberadaan UU No.5 tahun 1999: Hukum
} dan Harapan Masyarakat. FHUI, Depok, 1999, hal. 9. 


\section{Persaingan-Usaha yang Sehat dan Badan-Usaha Koperasi}

Sekarang timbul pertanyaan, adakah manfaat dari persainganusaha yang sehat ini terhadap badan-usaha lain khususnya Koperasi? Kemudian, mengapa pula ketentuan yang mengatur tentang persaingan-usaha yang tidak sehat memberikan "pengecualian" kepada badan-usaha koperasi?

Manfaat utama dari adanya ketentuan hukum tetang persaingan yang sehat terhadap koperasi secara langsung adalah memberikan "kesempatan" untuk menjalankan usaha seluas mungkin demi meningkatkan kemampuan ekonomi dan kesejahteraan para anggotanya.

Seperti dikatakan di atas, bahwa konsep persaingan-usaha yang sehat ini secara nyata dapat dilihat dan dirasakan baik oleh produsen maupun konsumen; dalam pengertian hukum dijabarkan sebagai "mencegah" terjadinya perbuatan curang. Kalaupun terjadi perbuatan curang, maka telah ada ketentuan hukum yang mengatur tentang sanksi-sanksi nya.

Khusus untuk Koperasi (yang umum-nya mempunyai kemampuan modal yang terbatas), adanya situasi persaingan yang sehat, membuka kesempatan yang luas kepada-nya untuk dapat ikut masuk ke dalam kancah aktivitas membuka dan menjalankan usaha. Tambahan lagi, dengan adanya ketentuan tentang larangan persaingan usaha yang tidak sehat tersebut telah memberikan ruang pengecualian ${ }^{49}$ terhadap badan-usaha koperasi yang melayani "kebutuhan" para anggotanya ${ }^{50}$.

Dengan demikian badan-usaha Koperasi -di lapangan seharusnyadapat melakukan kegiatan usaha apa saja yang terbuka; asalkan mampu untuk melakukannya dalam arti menerapkan prinsip-prinsip ekonomi dalam menjalankan usaha.

Pengecualian terhadap Koperasi dalam ketentuan tentang Persaingan-Usaha yang Tidak Sehat tersebut mempunyai "benangmerah" dari amanat Konstitusi Negara seperti yang dirumuskan dalam

${ }^{49}$ Pengecualian sebagaimana yang diatur dalam Pasal 50 butir (i) UU No. 5 tahun 1999, ..."Kegiatan usaha Koperasi yang secara khusus bertujuan untuk melayani anggotanya".

${ }^{50}$ Noer Sutrisno, Koperasi Indonesia: Konteks KehidupanPerekonomian, dapat dilihat dari kemampuan untuk menciptakankekuatan Potert dan Tantangan, selanjutnya dikatakan, ..." Secara teoritis, sumber kekuatan koperasi sebagai badan-usaha dalam monopoli dengan derajat monopoli tertentu. Tetapi ini adalah kekuatan semu dan justru dapat menimbulkan bagi anggota masyarakat di luar koperasi..." Sumber: >http://www.ekonomirakyat.org/edisi17/artikel.1htm>, diakses 12 November 2004. 
Pasal 33 UUD 1945. Dengan demikian, Koperasi secara legal dapat menjalankan usaha dengan baik tanpa khawatir dengan larangan praktek monopoli seperti diatur dalam UU No,5 tahun 1999 serta tidak menutup persaingan yang sehat.

Perlakuan khusus terhadap koperasi tersebut telah tercantum dalam konstitusi kita khususnya tentang penataan perekonomian nasional yang menjadikan koperasi sebagai salah satu sokoguru ${ }^{51}$. Untuk itu, pemerintah dalam hal ini harus konsisten kepada amanat konstitusi tentang sistem dan tingkah-laku para pelaku ekonomi secara keseluruhan dalam menjalankan perekonomian nasional ${ }^{52}$.

\section{Pembinaan Badan-Usaha Koperasi dan Pengaruhnya Terhadap Perasingan Usaha}

\section{A. Dasar Hukum Pembinaan Badan-Usaha Koperasi}

Dasar-Hukum Utama pembinaan Badan-Usaha Koperasi adalah UUD 1945.

Dengan demikian, di Negara kita Indonesia, satu-satunya bangunusaha yang mendapat mandat langsung dari konstitusi negara adalah Koperasi $^{53}$. Mandat tersebut kemudian diimplementasikan secara teknis dan kelembagaan dalam ketentuan perundang-undangan tentang Perkoperasian yang berlaku dewasa ini $^{54}$.

51 UUD 1945, Penjelasan Pasal 33., ..."Kemakmuran masyarakatlah yang diutamakan, bukan kemakmuran orang seorang. Sebab itu perekonomian disusun sebagai usaha bersama berdasarkan atas azas kekeluargaan. Bangun perusahaan yang sesuai dengan itu ialah koperasi."

${ }^{52}$ Lihat Penjelasan-Umum UU No.25 tahun 1992, yang berbunyi: ...,'Koperasi seharusnya mempunyai ruang gerak dan kesempatan usaha yang luas yang menyangkut kepentingan kehidupan ekonomi rakyat...." ..."sehingga semakin berperang dalam perekonomian nasional." ..."Pembinaan Koperasi pada dasarnya dimaksudkan untuk mendorong agar Koperasi menjalankan kegiatan usaha dan berperan utama dalam kehidupan ekonomi rakyat".

${ }^{53}$ Lihat lagi Penjelasan UUD 1945, Bab XVI tentang Kesejahteraan Sosial, Pasal 33; ..."Kemakmuran masyarakatlah yang diutamakan, bukan kemakmuran orang seorang. Sebab itu perekonomian disusun sebagai usaha bersama berdasarkan atas azas kekeluargaan. Bangun perusahaan yang sesuai dengan itu ialah Koperasi”.

54 Lihat Pasal 2 UU No.25 tahun 1992 tentang Perkoperasian, yang berbunyi: ..."Koperasi berlandaskan Pancasila dan Undang-Undang Dasar 1945 serta berdasarkan atas azas kekeluargaan". 
Kemudian, tidak cukup dengan dasar-hukum saja; Politik ekonomi negara kita secara implisit maupun eksplisit memberikan perlindungan dan perlakuan khusus kepada bangun-usaha Koperasi baik dalam bentuk pembinaan yang dilakukan pemerintah secara langsung maupun tidak langsung, maupun memberikan "perlakuan khusus" terhadap setiap lembaga ekonomi yang diwujudkan dalam bentuk Koperasi. Dengan demikian, menjadi jelas bahwa perwujudan nyata (secara juridis) dari politik-ekonomi negara yang berpihak kepada ekonomi kerakyatan. Oleh sebab itu, salah satu dari perlakuan khusus -yang dapat kita lihat- terhadap lembaga Koperasi adalah adanya "pengecualian" seperti yang diatur di dalam ketentuan perundang-undangan tentang persaingan-usaha yang tidak sehat ${ }^{55}$. Selanjutnya, berkaitan dengan adanya perlakuan khusus tersebut, pemberian perlindungan juridis melalui peraturan perundanganundangan adalah merupakan suatu bentuk-nyata dari peran pemerintah dalam membina dan mengembangkan usaha koperasi; hal ini dilakukan mengingat sampai saat ini bangun-usaha dan badan-usaha koperasi belum berkembang dan mendapat tempat seperti yang telah diamanatkan oleh konstitusi ${ }^{56}$.

Lebih dalam lagi, secara pilosofis, dasar-hukum pemberian perlakuan khusus kepada Koperasi tersebut merupakan konsekwensilogis dari konsep politik hukum-ekonomi kita tentang Koperasi sebagai sokoguru perekonomian negara seperti yang diamanatkan oleh konstitusi. Sehingga dalam kurun waktu dua-dekade tahun 1990an dan awal tahun 2000an, dapat kita temukan banyak sekali kebijakan yuridis dan praktis yang telah diambil Pemerintah untuk mengembangkan dan memajukan badan-usaha Koperasi ${ }^{57}$.

\section{${ }^{55}$ UU No.5 tahun 1999, Op. Cit., Pasal 50 ayat (h) dan (i).}

${ }^{56}$ Lihat juga komentar dari Ali Marwan Hanan selaku Menteri Negara Koperasi dan Usaha Kecil Menengah, ..."telah lama koperasi hanya dianggap kelas-dua dala keikutsertaannya membangun perekonomian di tanah-air ini, anggapan ini juga menempel pada usaha kecil-menengah...." Dikutip dari: Koperasi Sudah Lama Dianggap Kelas-Dua., $<$ http://www.gkbi.info.org/terkini/21.shtml>., diakses pada 12 November 2004.

${ }^{57}$ Upaya Pemerintah dalam mengembangkan dan membina usaha Koperasi antaralain dapat kita lihat Kebijakan Pemerintah membentuk KUD/BUUD ditahun 1970-80; sedangkan ditahun 1990an, kita kenal dengan mengundangkan UU No.25 tahun 1992 tentang Perkoperasian; kemudian di tahun 2001, ada Keppres No.127 tahun 2001 tentang Bidang Jenis Usaha yang Dicadangkan untuk Usaha-Kecil sampai dengan program ekspansi usahakoperasi untuk melakukan kemitraan. Walaupun demikian, perkembangan secara siknifikan memang belum terlihat. 


\section{B. Pengecualian Sebagai Wujud Pembinaan dalam Iklim Persaingan Usaha yang Sehat}

Pemberian perlakuan khusus kepada Koperasi yang disebut di atas membawa implikasi yuridis terhadap politik dan sistem perekonomian nasional; dalam konteks konstruksi persaingan-usaha yang sehat. Namun, dengan konsep perekonomian nasional yang disusun berdasarkan prinsip kebersamaan seperti yang diamanatkan oleh konstitusi, maka pengecualian terhadap lembaga bangun-usaha Koperasi tersebut merupakan dasar yuridis-praktis yang diletakkan Negara untuk memberikan peran yang lebih besar kepada Koperasi dalam nuansa menyusun dan membangun sistem perekonomian nasional.

Sampai dengan tahap pembinaan, sosialisasi sistim perekonomian negara dan bangsa yang dikelola berdasarkan sistim kekeluargaan perlu dilakukan secara intensif melalui lembaga-lembaga pendidikan masayarakat baik yang dikelola oleh pemerintah maupun swasta. Jadi unsure pembinaan ini harus dimulai dari sudut konsep-dasar, yang antara lain meliputi: pilosofi negara, dan budaya bangsa, serta adat istiadat (multicultural dan pluralisme) yang ada di Indonesia. Konsep ini merupakan modal-dasar dari pembinaan perkoperasian di Indonesia dalam membangun dan memperluas pemahaman tentang karakter perkoperasian yang berkarakter budaya bangsa Indonesia sendiri. Dari sisi ini, dibangun rasa kepercayaan diri ( baik selaku individu maupun bangsa) dalam memupuk modal untuk menjalankan usaha bersama. Sedangkan lembaga koperasi, dalam tahap ini merupakan suatu pilihan yang tepat dalam mewujudkan konsep dasar tersebut. Dengan demikian, bangun usaha lain seperti badan-badan usaha milik negara/daerah (yang sifatnya padat-modal) harus dipandang sebagai keterlibatan Negara secara langsung dalam menjalankan usaha untuk kemanfaatan rakyat-banyak, negara, dan bangsa; baik yang bersifat sebagai pelayanan-umum maupun bangun produksi dan industri.

Dengan demikian, lembaga koperasi tidak hanya dilihat dalam konteks normatif yuridis belaka, tetapi harus juga dipandang dari konteks sosial-ekonomis. Dalam konteks terakhir ini, titik berat usaha koperasi lebih ditekankan kepada aspek politik-ekonomi, sedangkan membahas koperasi dari sudut normatif-yuridis akan muncul aspek lembaga dan bidang-bidang usahanya ${ }^{58}$. Oleh karena itu, pemerintah

${ }^{58}$ Lihat lebih jauh, Didik J.Rachbini, "Politik Baru Menuju Demokrasi Ekonomi", (Jakarta: Grasindo, 2001), hal. 1. 
dalam rangka pembinaan, dapat saja memberikan peluang kepada koperasi untuk mengembangkan usahanya tidak saja hanya untuk melayani kebutuhan para anggotanya, tetapi dapat diperluas ke pelayanan umum untuk melayani kebutuhan riel masyarakat luas sepanjang kepentingan para anggotanya tidak terabaikan ${ }^{59}$. Disamping itu, pembentukan lembaga koperasi yang memberikan pelayanan kepada masyarakat umum tersebut, merupakan konsekwensi logis dari perkembangan usaha koperasi. Sehingga, dengan demikian, secara teknis dapat saja usaha dari sebuah koperasi itu berkembang dengan mendiversifikasi usahanya, sesuai dengan perkembangan kebutuhan para anggota dan masyarakat yang membutuhkannya.

Dalam kaitannya dengan iklim persaingan usaha yang sehat yang harus dipelihara dalam sistim perekonomian negara dan bangsa, harus dipandang dari sudut pilosofis: menjaga harmonisasi dan mencegah penguasaan sektor-sektor ekonomi yang menyangkut kebutuhan langsung dari rakyat banyak. Sehingga konsep-dasar ketentuan perundang-undangan persaingan usaha yang sehat ini akan berfungsi menjaga harmonisasi dari konser-perekonomian bangsa dan negara secara holistik. Dengan demikian, sistim perekonomian Negara Indonesia tidak hanya dipandang dari sudut sektoral belaka yang selama ini menarik garis pemisah antar peran koperasi sebagai sistim, peran badan-badan usaha Negara/daerah, dan peran lembaga-lembaga usaha yang dibangun oleh swasta. Semua ketentuan hokum positip harus diciptakan untuk mengakomodasikan kondisi dan situasi yang harmamoni. Untuk itulah peran ketentuan-ketentuan dalam bentuk hukum positip dan peran negara selaku regulator dan pengawas harus berfungsi maksimal.

Apabila konsep-dasar ini dapat diwujudkan, mustahil timbul pertanyaan-yuridis: Apakah terhadap Koperasi yang sudah menjadi Besar dan Kuat dalam arti modal dan jaringan-usaha, masih juga mendapat pengecualian? Untuk menjawab pertanyaan ini, ketentuan tentang Persaingan yang Sehat telah mengaturnya secara proporsional ${ }^{60}$. Jadi praksis, tidak perlu lagi ada keraguan dalam memandang lembaga koperasi yang besar dengan ketentuan perundang-undangan tentang persaingan-usaha yang tidak sehat.

${ }^{59}$ Bandingkan, Harjono Sumosudirjo, "Buku Pedoman Pengurusan Koperasi", cet. ke-7, (Jakarta: Kurnia Esa, tahun 2001), hal. 43.

${ }^{60}$ Pengecualian ini berlaku apabila koperasi tersebut hanya memberikan pelayanan khusus kepada para anggota-nya. Pasal 50 ayat (i) dari UU NO.5 Tahun 1999. 
Sampai pada taraf ini, "pengecualian" yang diberikan oleh regulator harus dibaca dalam konteks "membangun" kemakmuran rakyat melalui sistim ekonomi koperasi; sedangkan wujud lembaga-nya adalah Koperasi dalam fungsinya menjalankan usaha. Untuk itulah, tugas lanjutan dari pemerintah selaku Pembina lembaga Koperasi untuk -secara konsisten- ${ }^{61}$ memberikan porsi-porsi bidang-bidang usaha strategis yang hanya dapat dijalankan dan dimiliki oleh badanusaha Koperasi selaku lembaga.

\section{Hambatan Dalam Membina Badan-Usaha Koperasi}

Hambatan yang selama ini dirasakan secara umum dan menjadi penghalang dalam mengembangkan usaha koperasi dapat disebabkan dari faktor internal maupun dari faktor eksternal. Secara internal, umumnya dari sudut "kemampuan teknis" yang dimiliki oleh koperasi itu sendiri, yang dapat meliputi faktor-faktor: menejemen, pengalaman, jaringan-usaha, modal terbatas, serta kesadaran dari anggota baik secara individu maupun kolektif. Sedangkan secara eksternal, umumnya berasal dari kebijakan pemerintah yang sering tidak konsisten bahkan kontradiktf yang berakibat pada iklim yang tidak kondusif bagi perkembangan usaha koperasi.

Hambatan yang berasal dari internal koperasi, memang paling banyak kita temukan dimasyarakat. Dalam kasus ini, faktor pendidikan dalam arti luas menjadi sangat diperlukan, disamping peran pemerintah selaku Pembina (baik dalam konteks kelembagaan maupun dalam konteks teknis operasional). Dengan pendidikan (walaupun

${ }^{61}$ Mengapa harus konsisten? Selama ini, berbagai kalangan telah menyangsikan efektifitas dari kebijakanan pemerintah dalam melakukan pembinaan terhadap lembaga Koperasi. Hal ini dapat kita baca kritikan yang diberikan masyarakat tentang perkembangan koperasi dalam skala nasional yang masih akrab dengan permasalahan dalam mengembangkan lembaganya. Secara empiris, permasalahan itu dapat dikelompokkan dalam: Pertama, Iklim usaha yang tidak menunjang lembaga koperasi dalam menjalankan usahanya, meskipun pemerintah telah memberikan berbagai kemudahan-kemudhan; Kedua, pola kerjasama antar lembaga koperasi dalam menjalankan usahanya secara holistik belum terwujud, sehingga interaksi-usaha baik secara horizontal maupun vertikal masih harus dibenahi agar dapat membuka ruang yang cukup bagi perkembangan-usaha dari lembaga-lembaga koperasi yang ada di sekitarnya; Ketiga, kesadaran terhadap fungsi koperasi secara maksimal dapat membawa kemanfaatan bersama masih harus dibenahi secara serius; Kempat, keterbatasan pengalaman dan pengetahuan dibidang menejemen-usaha, informasi, dan lain-lain. Selanjutnya dapat dilihat lebih dalam, Ninik Widiyanti dan YW Sunindhia, dalam Koperasi dan Perekonomian Indonesia, Rineka Cipta, Jakarta, Cet. Ketiga, tahun 1998, hal.185. 
memakan waktu dan biaya) secara gradual, hambatan ini mustahil dapat dihilangkan.

Kemudian, hambatan yang berasal dari faktor eksternal koperasi, antara lain: dapat berasal dari kalangan birokrat pemerintah yang berwenang menentukan kebijakan. Terutama kebijakan dalam memberikan porsi-porsi usaha tertentu -yang dapat atau telah dijalankan oleh lembaga-usaha Koperasi- kepada badan-badan usaha non-koperasi. Secara empiris, kasus adanya kebijakan yang memberikan "perlakukan khusus" kepada lembaga-lembaga nonkoperasi sering terjadi dilapangan; hanya karena adanya faktor "kedekatan" hubungan dengan individu pejabat di kalangan birokrasi pemerintah $^{62}$.

Berdasarkan fakta tersebut, hambatan dalam mewujudkan keseimbangan persaingan usaha bagi koperasi justru dilakukan oleh kalangan pemerintah sendiri yang memberikan peluang-peluang usaha yang sebetulnya telah dikembangkan oleh lembaga koperasi yang ada selama ini. Dengan demikian, dalam kenyataan, memang sangat diperlukan konsistensi politik ekonomi dan kemauan politik dari pemerintah sendiri yang dapat "menolong" terciptanya perekonomian dengan konsep koperasi. Tanpa itu, semua yang selama ini di "impikan", tidak akan terwujud.

\section{Peluang Terciptanya Ekonomi Kerakyatan Dalam Konteks Koperasi Sebagai Sistim Perekonomian}

Pengecualian terhadap Koperasi yang diberikan oleh ketentuan perundang-undangan tentang Persaingan Usaha yang Sehat, harus dijadikan dasar yuridis dalam menciptakan peluang-peluang usaha koperasi secara luas. Koperasi dapat menjadi lembaga usaha dalam sistem perekonomian nasional. Karena, keberadaan koperasi baik

${ }^{62}$ Kasus pemberian izin operasi kepada PT Makro diawal tahun 1990an yang bergerak dalam usaha ritel dengan keanggotaan, berakibat "membunuh" usaha Koperasi "Trimitra" yang menjalankan usaha sejenis lebih dahulu dan telah mempunyai cabang di kotakota besar di nusantara. Kemudian disusul lagi dengan pemberian izin-usaha sejenis kepada usaha-usaha ritel lainnya yang bermodal asing seperti: Giant, Hypermarket, Range Market, Club Stores, dan lain-lain. Dengan terhentinya usaha Koperasi Trimitra (Produsen, PedagangKonsumen) tersebut, Pemerintah kemudian secara implisit merestui pendirian Koperasi "Goro" (singkatan dari Gotong-Royong) untuk menggantikan kedudukan Trimitra; namun dalam peristiwa 15 Mei 1998, seluruh perangkat keras koperasi Goro di nusantara terkena Bumi Hangus masal. Dengan demikian usaha-ritel yang digerakkan oleh Koperasi selama ini hancur total. 
sebagai sistem maupun lembaga ekonomi dapat hadir dimasyarakat kebanyakan dalam arti strata sosial paling bawah hingga di strata sosial tingkat atas dalam ukuran nasional bahkan internasional. Dengan demikian, koperasi dapat menjadi wadah dan kendaraan ekonomi rakyat dalam menciptakan tingkat kemakmuran sosialekonomi dari negara dan bangsa. Perlakuan khusus tersebut diberikan dengan alasan yang sangat mendasar, yaitu untuk memberikan kesempatan koperasi sebagai lembaga ekonomi untuk masuk dalam kancah usaha; baik di bidang perdagangan, jasa, maupun industri. Sehingga, dengan kondisi demikian, rakyat diberi kesempatan untuk masuk di salah satu bidang-usaha itu maupun duduk sebagai konsumen.

Selanjutnya, apabila rakyat katakanlah dari mereka yang berprofesi sebagai petani, dapat berkoperasi (misalnya dalam KUD sebagai unit terkecil) atau dalam sekala lebih luas membentuk koperasi dalam bidang komoditi sejenis yang menjalankan usaha perdagangan hasil pertanian mereka (bergerak dalam koperasi pemasaran bersama atau lebih luas lagi). Demikian seterusnya dapat diikuti oleh bidangbidang usaha rakyat lainnya seperti yang telah ada selama ini (ada KUD, Pertanian, Perikanan, Nelayan, Pemasaran, Industri, dan lainlain) dapat segera direvitalisasi atau jika belum ada lembaga koperasinya dapat didirikan koperasi-koperasi dalam arti lembaga didalam "kerangka" suatu sistem perekonomian-koperasi ${ }^{63}$.

Dengan demikian, peluang-peluang usaha yang dapat dilakukan oleh koperasi selaku lembaga, masih terbuka luas. Yang diperlukan untuk menangkap peluang ini tentunya harus diawali dengan "mimpi" besar untuk menjadi besar. Memang, dukungan konkrit dan konsistensi dari para penyelenggara Negara sangat diperlukan; tanpa ini proyek perekonomian koperasi akan tidak saja terbengkalai, bahkan dapat menjadi kenangan sejarah belaka; dalam arti kita secara bangsa gagal melaksanakan amanat konstitusi.

\section{Kesimpulan}

Berdasarkan diskusi di atas, ada empat kesimpulan yang dapat diberikan oleh penulis dalam diskusi terbatas ini, yaitu sebagai berikut:

${ }^{63}$ Pengertian "perekonomian-koperasi" disini, penulis artikan sebagai perekonomian yang dijalankan secara bersama dengan azas kekeluargaan; seperti yang dimaksud oleh Penjelasan dari Pasal 33 UUD 1945 kita. 
Pertama, dalam kedudukan Koperasi selaku lembaga yang menjalankan usaha, maka bukan tidak mungkin pada suatu periode dan situasi tertentu badan-usaha koperasi itu dapat masuk dalam kategori mejalankan praktek monopoli. Dengan demikian, apabila kondisi tersebut dipenuhi, maka ketentuan perundang-undangan yang mengatur tentang Larangan Praktek melakukan Usaha yang Tidak-Sehat dapat berlaku;

Kedua, beberapa persyaratan yang diberikan kepada lembaga usaha koperasi untuk dapat dikecualikan dari ketentuan Larangan Praktek Monopoli dan Persaingan Usaha yang Tidak-Sehat tersebut; antara lain dari segi permodalan dan luas lingkup pelayanan yang diberikan oleh badanusaha koperasi tersebut. Disamping itu, karena ketentuan Larangan Monopoli itu dibuat untuk menjaga harmonisasi kehidupan lembaga-lembaga usaha yang ada, maka kretaria dan ukuran dari lembaga usaha kecil (UKM) dan Koperasi memang harus diperjelas dan dievaluasi dari waktu ke waktu;

Ketiga, mengingat bahwa lembaga usaha koperasi merupakan usaha yang dibangun oleh kumpulan orang-orang (rakyat kecil) yang mempunyai modal terbatas dalam rangka meningkatkan kemampuan ekonomi anggotanya, maka pengecualian yang diberikan kepada badan-usaha koperasi itu diawali dengan niat pemerintah dalam hal memberikan dasar yuridis kepada lembaga-lembaga koperasi untuk mendapat kesempatan luas dalam memulai, menjalankan, dan mengembangkan usahanya secara luas; terutama untuk meningkatkan kesejahteraan ekonomi para anggotanya;

Keempat, ada hal-hal yang sering menjadi penghambat di lapangan dalam menjaga eksistensi usaha koperasi dan pengembangan usahanya adalah sikap pemerintah yang sering mendua dalam mengeluarkan kebijakan dengan memberikan porsi-porsi usaha yang sudah ditekuni dan dijalankan dengan baik oleh koperasi kepada pendatang baru dari kalangan lembaga usaha yang non- koperasi. 


\section{Daftar Pustaka}

\section{Buku dan Artikel}

Assiddiqie, Jimly. Konsolidasi Naskah Undang-Undang Dasar 1945 Setelah Perubahan Ke-empat. Pusat Studi Hukum Tata Negara, FHUI Jakarta, 2002.

Hadikusuma, R.T. Sutantya Rahardja. Hukum Koperasi Indonesia. Jakarta: PT Raja Grafindo Persada, 2000.

Hendrajogi. Koperasi: Azas-Azas, Teori dan Praktek. Jakarta: Rajawali Press, 1997.

Kwik, Kian Gie. "MPR dan Ekonomi Kerakyatan". Kompas, 16 Nopember 1996.

Mubyarto. Ekonomi Pancasila: Gagasan dan Kemungkinan. Jakarta: LP3ES, 1987.

Mutis, Thoby. Pengembangan Koperasi: Kumpulan Karangan. Jakarta: Grasindo. 1992.

. Ragam Koperasi di Manca Negara. Jakarta: Media Ekonomi Publishing, 1999.

Rachbini, Didik.J., Politik Ekonomi Baru Menuju Demokrasi Ekonomi. Jakarta: Grasindo, 2001.

Rahardjo, Dawam. Apa Kabar Koperasi Indonesia. Jakarta: Kompas Cyber Media, 2002.

Swasono, Sri Edi (Ed.). Mencari Bentuk, Posisi, dan Realitas Koperasi di dalam Orde Ekonomi Indonesia. Cet. Ke-2, Jakarta: UI Press, 1985.

Lapenkop Bukopin. Lebih mengenal Koperasi, Anggaran Dasar Koperasi, Rapat Anggota, SHU Anggota Koperasi. Cet. Ke-3, Bandung: Lapenkop Bukopin, 1999.

Widiyanti, Ninik dan Sunindhia. Koperasi dan Perekonomian Indonesia. Cet. Ke-3, Jakarta: Rineka Cipta, 1998.

Wiradiputra, Ditha. Hukum Persaingan Usaha di Indonesia: Perjanjian Yang Dilarang. Lembaga Kajian Persaingan Usaha dan kebijakan Usaha. FHUI Jakarta, 2003. 


\section{Peraturan Perundang-Undangan}

Indonesia, UUD 1945. Naskah Asli berikut Amandemen I, II, III, dan IV. ., UU No.25 Tahun 1992 tentang Perkoperasian.

., UU No.5 Tahun 1999 tentang Larangan Praktek Monopoli dan Persaingan Usaha Tidak Sehat.

., Keputusan Presiden No.127 Tahun 2001 tentang Bidang/Jenis Usaha yang Terbuka Untuk Usaha Menengah atau Besar dengan Syarat Kemitraan.

\section{Situs-Internet}

Hannan, Ali Marwan. "Koperasi Sudah lama Dianggap Kelas Dua", $<$ http://www.gkbi.info./terkini/21.shtml>, diakses 12 Nopember 20005.

Kusadrianto, M. Doddy. "Meñciptakan Persaingan Usaha yang Sehat Melalui Penerapan Prinsip Good Corporate Governance", $<$ http:www.fcgi.or.id/gcg\%20\&20persaingan\%20usaha\%2026-0203.pdf>, diakses 12 Nopember 2004.

Mubyarto. "Dari Ilmu Berkompetensi Ke Ilmu Berkoperasi" $<$ http:www.ekonomirakyat.org/edisi_16/artikel_htm>, diakses 12 Nopember 2004.

. "Membangkitkan Ekonomi Kerakyatan Melalui Gerakan Koperasi: Peran Perguruan Tinggi"., <http:www.ekonomirakyat.org/edisi_16/ artikel_3htm>, Diakses 12 Nopember 2004.

Soetrisno, Noer. "Koperasi Indonesia, Potret dan tantangan", $<$ http:www.ekonomirakyat.org/edisi_17/artikel_5htm>, diakses 12 Nopember 2004.

., "Koperasi Mewujudkan Kebersamaan dan Kesejahteraan: Menjawab Tantangan Global dan Regional Baru", $<$ http:www.ekonomirakyat.org/edisi_17/artikel_1htm>, diakses 12 Nopember 2004.

., "Koperasi Indonesia: Konteks Kehidupan Perekonomian dapat Dilihat Dari Kemampuan untuk menciptakan Kekuatan Potret dan Tantangan", <http:www.ekonomirakyat.org/edisi_16/ artikel_5htm>, diakses 12 Nopember 2004. 